\title{
Retraction: metastatic collecting duct carcinoma of the kidney treated with Sunitinib
}

El Mehdi Tazi ${ }^{*}$, Ismail Essadi ${ }^{1}$, Mohamed F Tazi ${ }^{2}$, Youness Ahellal ${ }^{2}$, Hind M'rabti $^{1}$ and Hassan Errihani ${ }^{1}$

\section{Retraction}

The authors have retracted this article [1] as it contains large portions of text and figures that have been duplicated from another article previously published in the International Journal of Clinical Oncology [2]. Lead author Dr Tazi accepts full responsibly for the duplication and would like to apologise to the co-authors, Editors and readers as well as the authors of the original article.

\section{Author details}

'Department of Medical Oncology, National Institute of Oncology, Rabat, Morocco. ${ }^{2}$ Department of Urology, CHU Hassan II, Fez, Morocco.

Received: 21 October 2011 Accepted: 24 October 2011

Published: 24 October 2011

\section{References}

1. Tazi EM, Essadi M, Tazi MF, Ahellal Y, M'rabti H, Errihani H: Metastatic collecting duct carcinoma of the kidney treated with Sunitinib. World Journal of Surgical Oncology 2011, 9:73.

2. Miyake $H$, Haraguchi T, Takenaka A, Fujisawa M: Metastatic collecting duct carcinoma of the kidney responded to sunitinib. International Journal of Clinical Oncology 2011, 16:153-155.

doi:10.1186/1477-7819-9-136

Cite this article as: Tazi et al:: Retraction: metastatic collecting duct carcinoma of the kidney treated with Sunitinib. World Journal of Surgical Oncology 2011 9:136.
Submit your next manuscript to BioMed Central and take full advantage of:

- Convenient online submission

- Thorough peer review

- No space constraints or color figure charges

- Immediate publication on acceptance

- Inclusion in PubMed, CAS, Scopus and Google Scholar

- Research which is freely available for redistribution

\section{Biomed Central}

